\title{
Learning through Assessment and Feedback Practices: A Critical Review of Engineering Education Settings
}

\author{
N. P. Subheesh ${ }^{1 *}$, Satya Sundar Sethy ${ }^{1}$ \\ ${ }^{1}$ Department of Humanities \& Social Sciences, Indian Institute of Technology Madras, Chennai, INDIA
}

Received 29 July 2019 - Revised 9 November 2019 • Accepted 12 November 2019

\begin{abstract}
'Assessment' and 'feedback' are inherently embedded in a course curriculum of engineering education settings. These components are indispensable for the teachinglearning processes. It is observed that engineering faculty members do not require any 'teacher-training' to join the engineering institutions across the globe. Hence, they may not have adequate experience in assessing students' performances and providing feedback to students. Only a few research studies have been carried out on assessment and feedback from the engineering education context. Therefore, this paper attempts to critically analyse the literature pertaining to learning through different types and methods of assessment practices in the engineering education settings. Further, it examines the significance of qualitative feedback in assessment and the principles of good feedback practice. It highlights the implications of assessing student performance and providing feedback from the engineering education perspective. Finally, the paper offers some recommendations on assessment and feedback practices in the engineering education settings.
\end{abstract}

Keywords: assessment, engineering education, evaluation, feedback, grading, quality assurance

\section{INTRODUCTION}

'Assessment' is an integral part of a course curriculum. It is an essential component of teaching-learning processes that influences students on the one hand and course teachers on the other hand (Dziob, Kwiatkowski, \& Sokolowska, 2018; Suskie, 2010). It motivates students to learn subject contents and assists them to enhance their learning. It guides them to identify strengths and weaknesses of their learning. The 'feedback' associated with assessment gives an opportunity to students to overcome the weaknesses of their learning (Irons, 2008). Further, assessment guides course teachers to evaluate their teaching performance of the courses that they offered to students. While assessing students' performances, course teachers get feedback on the instructional design and effectiveness of the courses (Black \& Wiliam, 1998; Wiliam, Lee, Harrison, \& Black, 2004). They identify the reasons for students' good and bad performance(s) of the course. By using the assessment results, course teachers check whether students have achieved the learning objectives of a course or not. Assessment, therefore, stimulates learning in multiple ways. It encourages and motivates students to learn the subject contents, helps them to identify their strengths and weaknesses of a course, and supplies information to plan what they need to do next (Subheesh \& Sethy, 2018; Yorke, 2008). However, as assessment and feedback evolve from time to time along with the course curriculum, instructional design, and course objectives; there are many challenges lie in assessment practices.

In the context of engineering education, the challenges associated with assessing students' learning are reasonably more significant. This can be attributed to engineering students' need to acquire the following features at the end of their study (Ewell, 1998; Leslie \& Gorman, 2016; Rompelman, 2000).

1) Engineering students need to develop the ability to design and conduct experiments, analyse and interpret data.

2) They need to develop the ability to use tools, techniques, and skills for engineering practice.

(c) 2020 by the authors; licensee Modestum Ltd., UK. This article is an open access article distributed under the terms and conditions of the Creative Commons Attribution License (http://creativecommons.org/licenses/by/4.0/).

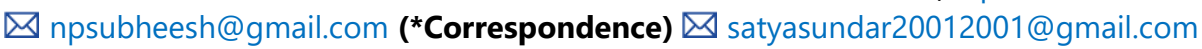




\section{Contribution of this paper to the literature}

- There are only a few research studies available on assessment and feedback practices in the engineering education context. This paper addresses the research gap by providing a critical review of assessment and feedback in engineering education settings.

- The present paper is unique in its contribution to the existing literature in terms of illustrating the interrelationship among 'assessment', 'evaluation', and 'grading' in engineering education.

- This study offers some key recommendations for improving the quality of assessment and feedback practices in engineering education. The paper highlights specific challenges encountered while assessing engineering students' performances, which require further research exploration.

3) They are required to develop the ability to work in a collaborative and multidisciplinary team.

4) They are expected to develop an understanding of professionalism and take ethical responsibility for their tasks.

5) They need to develop the ability to communicate information effectively.

To accomplish these objectives engineering students must possess the subject knowledge and skills to become engineering professionals. In this viewpoint, assessment plays a vital role to assist students in knowing about their knowledge and skills in engineering courses (Mallet, 2008). Burtner (2000) argue that engineering students require certain skills (such as analytical skills, problem-solving skills, communication skills, team working skills, etc.) that would not be assessed adequately by traditional assessment practices. There is a need for the development and implementation of more effective assessment practices in engineering education settings.

According to Suskie (2010), establishing clear, measurable expected outcomes of student learning must be the aim of good assessment practice. Literature pertaining to engineering education conveys that engineering faculty members are not getting adequate research guidance on how to develop the instructional design of a course and establish measurable learning outcomes (Burtner, 2000; Palmer, 2004; Rompelman, 2000; Sethy, 2018). They are prone to commit an error while designing instruction of a course. Again, they may not be able to formulate effective assessment strategies and assessment tools of a course. Palmer (2004) emphatically enunciates that engineering faculty members may seek assistance from experts, where required, to develop appropriate assessment strategies for their courses. Burter (2000) expresses that formulating measurable learning outcomes and assessing students' performances are sophisticated activities with which most engineering faculty members have had little or no experience (p.4). In this regard, Serin (2015) argues there is a need for high-quality teacher-training in instructional design and assessment practices.

With regard to engineering education settings across the globe, it can also be observed that engineering faculty members need not go through teacher-training programmes or certification programmes to teach engineering students (Bhattacharya, 2004; Palmer, 2004; Subheesh \& Sethy, 2018). This may result in causing difficulties to them to develop appropriate assessment tools and techniques of a course. They often encounter difficulties in assessing students' learning objectives appropriately. It is stated that adopting a wrong or inappropriate assessment practice misguides students for their learning improvement and provides wrong information to them about where they stand in a course. It conveys a wrong message to the stakeholders about the achievements of engineering graduates of a course (Oyinloye \& Imenda, 2019). Inappropriate or wrong assessment practices thus hurdle in achieving the engineering education objectives in the higher education setup.

McGourty (1999) points out that integrating appropriate assessment practices into academic programmes has to be a major goal of every engineering educational institution. McDowell, White and Davis (2004) state that engineering departments are often criticised by their students and by external quality reviewers, for paying insufficient attention to the effective implementation of appropriate assessment practices. Christoforidou, Kyriakides, Antoniou, and Creemers (2014) enunciate that researchers need to identify problems associated with engineering assessment practices and tackle those by removing the barriers for the effective implementation of appropriate assessment practices in the higher education setup (p.2). In Shaeiwitz (1996) view, to implement an appropriate assessment practice on a course in an engineering education institution, engineering faculty members culture is required to be amended, so that they will comprehend the importance of assessing students' performances and its relation with students' learning objectives.

In this backdrop, this article critically investigates how students' course content learning can be improved through assessment and feedback practices in engineering education settings. 


\section{NATURE, SCOPE AND DEFINITIONS OF ASSESSMENT}

The expression 'assessment' is derived from the word 'assess'. The word 'assess' means 'judge the extent of learning' (Black \& Wiliam, 2009) in the context of 'education' as a study of the discipline. The term 'assessment' is explained by the US, UK, and South Africa higher education boards in their policy documents in the following ways.

'The Committee on the Foundations of Assessment' under the Board on Testing and Assessment, Centre for Education, US states that "assessment is a procedure by which course teachers use students' responses to specifically designed stimuli to draw inferences about students' knowledge and skills" (Pellegrino \& Chudowsky, 2003). The United Kingdom Quality Assurance Agency for Higher Education in its code of practice states that 'assessment' in higher education used to appraise a student's knowledge, skills, understanding, and abilities (Joughin, 2009). The South African Department of Education (DoE), in its 'Revised National Curriculum Statement (RNCS)' defines assessment as "a continuous, planned process of gathering information about the performance of learners judged against the learning outcomes" (Kanjee \& Sayed, 2013).

According to Scriven (1967), 'assessment' is defined as a judgement process which can be conducted according to predefined goals or criteria, yielding either comparative or numerical ratings. It is necessary to justify the datagathering instruments used and the selection of goals or criteria (p.40). Taras $(2005,2009)$ conveys that assessment is required to justify the judgement process itself against the stated goals and criteria. Taras argues that Scriven's definition of assessment does not specify how assessment facilitates student learning. Black and Wiliam (1998) define 'assessment' as a planned activity where judgements are made about the quality of student learning performances. The assessment information is used to facilitate student learning and to certify students for their learning achievements. Weurlander (2012) endorses Black and Wiliam's views by offering a similar definition of assessment. It expresses that assessment can be used to provide feedback to students in order to improve their learning and summarise their achievements in order to grade and certify them (p.747).

Sadler (2005) describes 'assessment' as the process of forming a judgment about the quality and extent of student achievement or performance of a course. In his opinion, such judgements are obtained from students' assignment responses. Course teachers assess students' performances to appraise the extent of their learning on course contents. In the process of judging students' performances, course teachers verify whether the course objectives are getting achieved or not. The attainment of aims and objectives of the course obtained from the assignment task would help the students to identify their quality of learning on course contents (Bryan \& Clegg, 2006; Trigwell \& Prosser, 1991). Joughin (2009) explains assessment as making judgements about students' work, informing them what they know in a course, and what they are capable of learning with regard to course contents.

In the context of engineering education, Cruz et al. (2019) defines 'assessment' as a process to judge students' level of mastery in;

1) subject knowledge and technical knowledge in their respective engineering disciplines

2) competencies such as communication skills, creative thinking/innovation, lifelong learning and teamwork skills ('employability skills' to enter into the engineering profession)

Even though there are many definitions available for 'assessment', this article subscribes to the following definition in the engineering education context. That is, 'assessment' is judging engineering students' performance by awarding them score/mark about the quality and extent of their achievements and providing qualitative feedback that helps them to shape their learning to become engineering professionals (Sethy, 2018; Subheesh \& Sethy, 2018).

With regard to learning contents of a course, assessment informs students where they stand in a course. Assessment conveys what they achieved in a course (Suskie, 2010). Further, it informs what level of knowledge and skills achieved by students for a profession (e.g. medicine, engineering, etc.). Moreover, assessment supplies information to the stakeholders (the employer) those may consider passed out students of certain courses for the employment in their organisations (Yorke, 2003, 2008). It is also noticed that there are cases where employers shortlist passed out students of a university or an institution for employment based on their results in certain courses. This phenomenon is observed with regard to university/institution placement time.

Students recognise their strengths and weaknesses in a course based on the assessment feedback. Effective feedback on an assignment can help a student to find out his/her mistakes and wrong understanding of content learning (Bhagat, Subheesh, Bhattacharya, \& Chang, 2017). Feedback would increase a student's confidence and motivation to learn the course contents. According to Mumm et al. (2016), students' active participation in reading the assessment feedbacks and using them for the benefit of their learning is crucial for efficient and effective learning practice.

Course teachers also get benefit from the assessment practices. The assessment helps teachers to receive feedback on the instructional design of the course while assessing students' assignment responses. Assessment is 


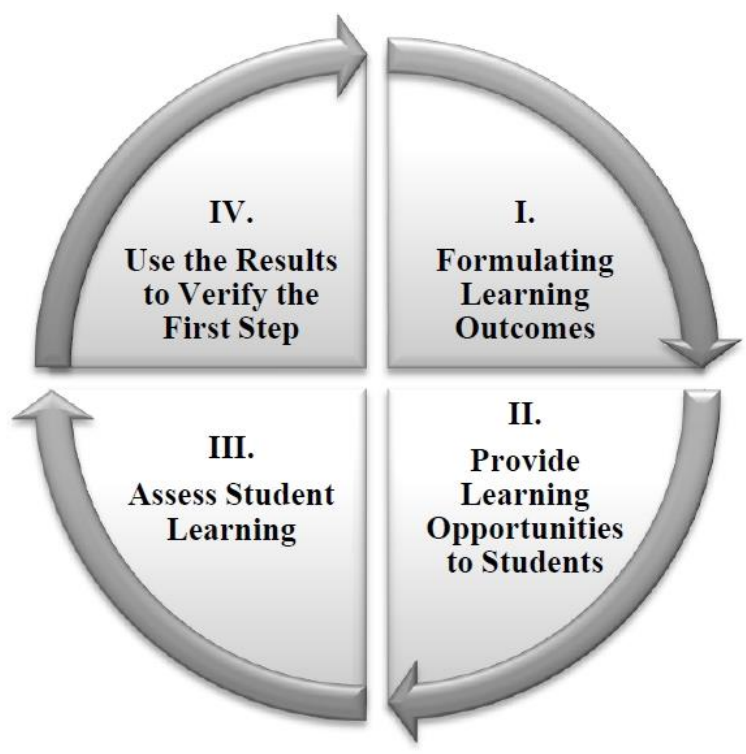

Figure 1. Four Steps of Assessment Practices

considered as a powerful tool to judge teacher's teaching effectiveness (Kristensen \& Sørensen, 2004). While assessing students' responses, course teachers can identify the causes for students' good or bad performances on learning. This, in turn, can be used as valuable feedback to improve the teaching-learning process of the course. According to Hanna and Dettmer (2004), assessment is the means by which course teachers accumulate information about their teaching instructions of a course and students' learning as well. Macfarlane (2009) emphatically states that course teachers' success depends on their capabilities to nurture the academic growth of students and to act as a critic of their own teaching effectiveness. These capabilities of course teachers depend on the assessment practices adopted by them.

To summarise, assessment can be described as the following four-step cycle.

1) It formulates the course objectives.

2) It ensures to provide learning opportunities for students to attain the course objectives.

3) It assesses students' performances and finds out how far they achieve course objectives.

4) It uses assessment results to redesign the instruction of a course for the benefit of students' learning if any.

The four steps involved in an assessment practice is depicted in Figure 1.

From the engineering education perspective, the nature and scope of assessment depend on certain specific traits of engineering studies. Engineering students are expected to acquire theoretical and technical knowledge in their respective engineering disciplines. They are expected to possess high-quality oral and written communication skills to convey their knowledge (Choudhury, 2019). According to Cruz et al. (2019), engineering students are supposed to attain an ability to work as competent team members in an interdisciplinary collaborative environment. Eventually, students are expected to get hold of engineering practices to evolve as engineering professionals (Lal et al., 2017; Subheesh \& Sethy, 2018). Assessment and feedback practices can continuously monitor and improve engineering students' progress in all these requirements.

In this regard, Palmer (2004) states that traditional forms of assessment found in higher education (such as written examinations) may not be rational representations of engineering practices. He points out that even though traditional assessment forms are easy to administer, it is better to go for more authentic assessment practices like a project-based assessment to reflect real-world engineering practices. He is of the view that the industrial community across the globe considers theoretical knowledge and technical competencies of engineering graduates as 'satisfactory'. On the other hand, their ability to make sound technical reports and presentations, ability to communicate well, ability to innovate, ability to effectively involve in teamwork, and ability to update their knowledge (through lifelong learning) are not up to the mark as per engineering industry standards (Cruz et al., 2019; Rompelman, 2000). Thus, in order to prepare students for their potential engineering profession, more importance has to be given in developing their competencies in communication, innovation, teamwork, and lifelong learning in addition to technical competency. The nature of assessment practices and policies in engineering education would assist students in obtaining these competencies. Assessment and feedback have to be carefully designed in a way to ensure students' attainment of the competencies and skills. However, assessing engineering 
students' proficiency in such competencies and skills is a complex process (Cruz et al., 2019). Development of efficient assessment and feedback practices in engineering education demands 'an extraordinary effort and time commitment' (Vos, 2000).

Furthermore, an engineering course curriculum is characterised by the application of theoretical concepts to address practical engineering problems. Developing practical skills of students is, therefore, an essential component in every engineering course. Consequently, the assessment practices in engineering education are along the lines of practical works. A proper assessment can ensure students' active involvement and engagement in practical laboratory work in engineering subjects (Clancy, Quinn, \& Miller, 2005). In particular, the assessment practice can focus on assessing students' ability to collect experimental data, perform data analysis, interpret analysis results, and investigate the cause of malfunctions of engineering artefacts (Abdulwahed \& Nagy, 2009; Lal et al., 2017).

\section{SIGNIFICANCE AND RELEVANCE OF ASSESSMENT IN HIGHER EDUCATION}

Assessment is an inalienable component of the instructional design of a course. Irrespective of educational programmes, it is an indispensable component of a course (Angelo \& Cross, 1993). With regard to higher education settings, assessment aims at achieving three objectives - learning, certification, and quality assurance (Yorke, 2008).

The term 'learning' includes;

1) motivating students,

2) diagnosing strengths and weaknesses of students,

3) providing feedback to the students about their course content learning,

4) helping students to develop their ability for the self-assessment practices,

5) informing the achievement level at the end of a unit of study.

The 'certification' subsumes;

1) establishing the achievement level at the end of a programme of study,

2) passing or failing a student,

3) grading a student in a course and a programme,

4) granting a 'license' to practice a profession, if any,

5) assisting students for employment and further educational study, if any.

6) predicting the future performance of a student based on the knowledge and skills earned in a course.

The expression 'quality assurance' incorporates the following;

1) It assesses to what extent a programme's aims and objectives are achieved.

2) It examines the effectiveness of the learning environment.

3) It provides feedback to the course teachers regarding their teaching effectiveness.

4) It assures interested parties (e.g. employers) about the standard of the programme.

5) It encourages good practices in the respective profession (e.g. medicine, engineering, etc.).

Yorke (2008) states that assessment does two duties: ostensive duty and tacit duty. Ostensive duty is one where students get immediate benefit from the assessment feedback. It conveys the identifiable and measurable growth of students' and teachers' involvement in a course (Worth-Butler, Murphy, \& Fraser, 1994). For example, an engineering student learns that he/she has good analytic skills through assignment feedback comments. 'Tacit duty', on the other hand, helps students to prepare themselves for future learning after passing out a course. It guides students for their overall growth, which are not measurable, but conceivable and realizable. For instance, it can be enhancing positive attitudes toward self-assessment practices, improving critical thinking skills, or developing analytical writing-cum-presentation ability.

Natarajan (2000) states that there is a global interest noticed among scholars, researchers, and institutions to assure quality in the higher education set up. In this regard, researchers have identified some parameters to retain quality in the teaching-learning process. These are; formulating the learning objectives of a course, finding out the attainment of course objectives through assessment tasks, and providing qualitative feedback to students in a timely manner (Deeley \& Bovill, 2015; Gaertner, 2014; Wiliam et al., 2004). All these parameters are related to assessment practices. Thus, assessment plays a pivotal role in ascertaining quality in higher education settings to some extent (Yorke, 2008). Along the same lines, Sadler (2012) evokes that if integrity in assessment practices is achieved tolerably well, it would be possible to ensure the quality of the teaching-learning process. In his view, maintaining integrity in assessment helps in discovering information on 'actual' achievements of students' learning. That information can be used as feedback to modify the instructional design of a course and thereby improve the 
overall learning quality. He vehemently states that through better assessment practices, quality assurance in higher education can be ascertained (Sadler, 2005, 2012).

As engineering education is a part of higher education, all the three objectives of assessment in higher education (learning, certification, and quality assurance) apply to engineering education as well. However, specific purposes of assessment practices in engineering education are dependent on engineering students' learning features. Students graduating with an engineering degree are expected to possess certain explicit learning features and professional skills as per the objectives of engineering education (Rompelman \& De Graaff, 2006). These consist of understanding engineering course contents with strong theoretical foundation, applying engineering tools and techniques to solve real-world problems, developing research skills, preparing proper documentation, fostering the ability to work in a multidisciplinary team, developing effective communication skills, etc (Lal et al., 2017; Olds, Moskal, \& Miller, 2005). According to Rompelman (2000), assessment of students' learning in engineering courses can be used to enhance learning features and professional skills. The significance and relevance of assessment practices in engineering education lie in how assessment can be used to equip students to transform as engineering professionals. Specifically, assessment and feedback can be used for the following purposes in engineering education.

1) Assessment can be used for improving students' capability to solve real-world engineering problems with the application of theoretical knowledge of engineering science and mathematics (Ewell, 1998; Froyd, Wankat, \& Smith, 2012). This can be done by assessing students' problem-solving skills through quizzes/assignments and providing proper feedback (Oyinloye \& Imenda, 2019).

2) Assessment can be used to develop engineering students' practical skills. These include designing and conducting proper experiments, analysing and interpreting experimental data, and an ability to make the right decisions from the observations. These skills can be assessed based on students' laboratory work, and feedback can be given to enhance them (Abdulwahed \& Nagy, 2009; Clancy et al., 2005).

3) Assessment practices can enhance engineering students' oral and written communication skills, which are essential for them in their prospective engineering profession (Cruz, Saunders-Smits, \& Groen, 2019; Olds et al., 2005). This can be achieved by assessing class seminars, technical reports, etc., and providing qualitative feedback to students to improve the quality of presentation.

4) Assessment can help students to work efficiently in a collaborative environment (Mallet, 2008). Teamwork based projects can be integrated into engineering course curriculum. Students can be evolved as good team players by proper assessment and feedback of project-based learning (Chua, 2014). Qualitative feedback can be provided to develop students' skills in leadership, planning tasks, and achieving goals as a team (Powell, 2004).

5) Assessment can also be used for making engineering students realise their professional, moral and ethical responsibilities in the engineering profession. This can be done by courses like 'professional ethics' and integrating ethical aspects in engineering courses (Cruz \& Frey, 2003; Sethy, 2017). Effective assessment and feedback on ethical lessons can help students to make the right judgments in their future engineering profession.

\section{REVIEW OF ASSESSMENT TYPES}

According to higher education literature, there are two types of assessment - formative assessment and summative assessment. Formative assessment (FA) is popularly known as 'assessment for learning' (MacLellan, 2001). There is no equivocal definition of formative assessment which is agreed to all educational researchers (Andersson \& Palm, 2017). According to Irons (2008), FA is the task or activity which provides feedback to students about their learning. It does not carry a quantitative score which is subsequently used to generate the final gradesheet of a course. Instead, it contains a qualitative feedback component, which is offered by course teachers to students for the improvement of their course contents learning. In this regard, the formative assessment may be judged as dialogic and conversational in intent as it seeks to engage students in identifying the ways and means to improve course contents learning (Oyinloye \& Imenda, 2019).

Formative assessment is aligned with course objectives. FA helps in achieving the desired level of students' performance in a course (Yorke, 2008). Through FA, the course teachers know whether to modify the instructional design of a course or not. Yorke (2003) suggests that the basic principle behind formative assessment is to "contribute to student learning through the provision of information about performance" (p.113).

Irons (2008) defines summative assessment (SA) as an activity that results in a mark or a grade which is subsequently used to generate the final grade or score of a course. Here students' receive the 'final language' in the form of mark/score (Oyinloye \& Imenda, 2019). SA marks are used for grading students in a course at the end of a semester (Mumm et al., 2016). It measures the students' achievements of course objectives and reports the same to the students and the other stakeholders of the course. Summative assessment is stated as 'assessment of learning'(Bakx, Baartman, \& Van Schilt-Mol, 2014). 'Assessment of learning' occurs at the end of a semester. SA 
contributes to generating the final grade of a student at the end of a course (Taras, 2005, 2009). It is also used to certify the required level of abilities, skills, and competencies achieved by students in a course.

Black and Wiliam (1998) argue that SA emphasises largely on examinations, and not contribute positively to student's motivation for further learning. According to them, SA is not a good means to find out what students know about the course contents. Rather, FA with qualitative feedback on students' performances is the correct means to find out students' achievement of a course, as it motivates them for better learning. Overall, FA helps students to learn the course contents thoroughly and attain the course objectives to the possible extent.

Summative assessment and formative assessment seldom overlap with each other. For example, a course has two quizzes and one end semester examination. Each quiz carries 20 marks and end semester examination carries 60 marks out of the total marks 100. With regard to quiz-1, let us say, students get qualitative feedback on their examination performance - it is known as FA. Along with qualitative feedback if students are awarded a score/mark for their performance, then it is known as SA. Quiz-1 marks and quiz-2 marks are added to the end semester examination marks to generate the final mark or grade of a course. It is noted that a summative assessment may serve a formative role in a context where data obtained from SA may be used to inform learners how shall they do well in the next semester courses, and how to perform better in the upcoming courses (Taras, 2009).

The difference between FA and SA can be described with an analogy. Let us consider, a cook has prepared a soup and served to his/her guest. When the cook tastes the soup while preparing the soup, to check whether it tastes good before serving to the guest, then it is analogous to FA. The reason is there is a chance for the cook to improve the taste of the soup better by adding ingredients to it. In a similar way, FA has a provision to help students to improve their learning through feedback. But if the cook without tasting the soup serves the guest, where there is no scope of improving the taste of the soup, then it is analogous to SA. In summative assessment practice, students do not get an opportunity to improve their learning as they do not receive any qualitative feedback on their assignment responses (Gulikers, Biemans, Wesselink, \& van der Wel, 2013; Trotter, 2006).

\section{REVIEW OF ASSESSMENT METHODS}

Assessing students' assignment responses require a method through which judgments are made. There are two methods to assess students' assignment responses - Norm-Referenced Assessment (NRA) and CriterionReferenced Assessment (CRA). In a course, if a student's achievement is judged in comparison with other students' achievements then it is regarded as a norm-referenced assessment. But if a student's achievement is assessed based on the course learning outcomes then it is regarded as a criterion-referenced assessment.

In NRA, a course teacher judges a student's achievements comparing with his/her classmates' achievements on an assignment (Boud, Cohen, \& Sampson, 1999). According to Lesage, Valcke, and Sabbe (2013), NRA builds a 'relative' model that compares the learning performances of a group of students enrolled in a course. It informs where a student stands in relation to other students in a class with regard to achievement of course objectives (Gibbs \& Simpson, 2004). Even without achieving all the course objectives, there is a possibility that a student may stand first in a class.

NRA is colloquially known as 'grading on the curve'. It is so because the grade sheet of students in a class is designed through 'bell-curve' (Knight, 2001). It is observed that in NRA, course teachers may require to push some students to higher grades and pull some students to a lower grade to design the 'bell-curve'. Thus, NRA practice is regarded as a relativistic account of assessing students' performance of a course (Gibbs, 2006; Gibbs, Simpson, \& Macdonald, 2003). In this method of assessment, course teachers compare a student's achievements with his/her classmates on an assignment task, and therefore course teacher's subjective and biased judgements on students' assignment task may not rule out. Thus, the NRA method does not communicate students' about their real achievements of a course and thereby misguides the students to some extent (Hassan, 2011). NRA promotes an individual's learning achievements in comparison with others (Boud, 2000; Boud et al., 1999). It does not justify whether the course objectives are achieved or not.

In contrast, criterion-referenced assessment method is considered as a realistic account of assessment practice (Yorke, 2008). In this case, a student's performance is assessed through a set of criteria, i.e. course objectives. According to Lesage, Valcke, and Sabbe (2013), CRA is based on an absolute standard that judges students learning achievements with reference to predefined course objectives. CRA justifies a student's achievements of a course in line with his/her earned knowledge of course contents.

In CRA, course teachers' judgments on students' performances are made based on the achievements of course objectives (Hassan, 2011). It may be possible that in CRA practice, each and every student of a class would achieve all the course objectives and thereby awarded with a higher grade, let's say ' $S$ ' grade. CRA practice brings the relationship between the course objectives achievements and the scores awarded to the students' performance (Sadler, 2005). In CRA, to what extent a student achieves the intended learning outcomes of a course is judged 
(Yorke, 2008). Biggs (1999) enunciates that in CRA, a correlation exists among course objectives, assessment tasks, and teaching and learning activities.

In recent years, higher education institutions across the globe are giving more importance to the adoption of CRA (Sadler, 2005). This can be attributed to the NRA's inability to communicate students' real achievements of course learning objectives. Instead, NRA misguides students and other stakeholders like employers. As NRA is done by comparing every student's learning achievements with other students, students may not be able to know their actual achievement level with reference to the course objectives. Employers will also be misguided by the misrepresentation of students' achievement levels offered by the NRA (Knight, 2001). Conversely, as CRA is done by judging students' achievements of course objectives, they would be able to know their real achievement level (Hornby, 2003). CRA informs employers the same - students' real achievements in a course. It is considered as the 'professional assessment practice' (Sethy, 2018; Yorke, 2008).

In engineering education, since it is a part of higher education, there is a similar trend of adopting criterionreferenced assessment. CRA's effectiveness and strong theoretical rationale are making it preferred over NRA. However, there are some major problems for engineering educators in shifting from NRA to CRA. It can be attributed to engineering educational institutions' different conceptions of what CRA means in theory and practice. According to Yorke (2008), the effectiveness of CRA is dependent on the accuracy by which the assessment criteria are stated and implemented. It is observed that even the basic statements of assessment criteria (to judge students learning achievements) are often too vague (Sadler, 2005, 2009). There exist manifold interpretations of what criteria mean and how can it be implemented.

There is a dearth of proper documentation and guidelines on developing assessment criteria to judge students' learning in engineering courses (Rompelman, 2000). As stated by Vos (2000) and endorsed by Suskie (2010), there has to be a section on institutional policy documentation, providing detailed guidance on how judgments about student learning achievements can be done. Various engineering departments in the institution can develop discipline-specific assessment criteria aligned with respective course objectives. Providing detailed guidance on assessment criteria is particularly important in engineering education settings, because most of the engineering educators have minimal experience in developing effective assessment practices (Burtner, 2000). In Sadler (2009)'s view, designing precise assessment criteria and using them for judging students' performances are sophisticated activities. It demands a basic knowledge of educational theories and more time and effort from the educator. In this regard, engineering educators can seek help from educational experts to develop precise assessment criteria (Palmer, 2004). There is a necessity for coherent research and discourse on the design, development and implementation of CRA in engineering education.

\section{THE RELATIONSHIP AMONG ASSESSMENT, EVALUATION AND GRADING}

In the higher education context, the term 'evaluation' refers to awarding a quantitative score to a student's performance (Scriven, 1994). It does not include qualitative feedback. Evaluation is purely quantitative in nature. 'Feedback' is not an integral part of the evaluation. In contrast to evaluation, assessment includes qualitative feedback necessarily (Irons, 2008). Thus, assessment is 'qualitative', and evaluation is 'quantitative'. The assessment feedback is used to improve students' learning and course teachers' teaching, whereas evaluation score or grade does not assist a student in learning the reasons for receiving certain score or grade on his/her performance. Further, students may not know how to improve in the subject content's learning, and in which ways, etc. In this sense, the evaluation score brings ambiguity in students' minds pertaining to their performances.

There are two types of assessment and two kinds of evaluation practices found in the higher education settings. These are; formative assessment (FA), summative assessment (SA), formative evaluation (FE), and summative evaluation (SE). Let us explain these four components with an example. In an engineering course, if a course teacher provides qualitative feedback on students' assignment responses, then it is regarded as FA. But if the course teacher awards a grade or a score on students' assignment responses, then it is treated as FE. If a course teacher provides qualitative feedback along with marks or scores or grades on students' assignment responses, then it is treated as SA. There are some higher education institutions across the globe, where course teachers give feedback on students' assignment responses along with a grade or a score. This is found in the case of quiz-1, quiz-2, etc. In this case, quizzes marks are counted to generate the final grade sheet of a course. Summative Evaluation (SE) is the total marks received by students at the end of a course. For example, a student gets 82 out of 100 marks in a course. The total marks include quizzes' marks and end semester examination marks. At the end of the course, students are awarded a final grade or mark where no qualitative feedback is offered. The representation of types of assessment and evaluation and their interconnections are depicted in Figure 2. 


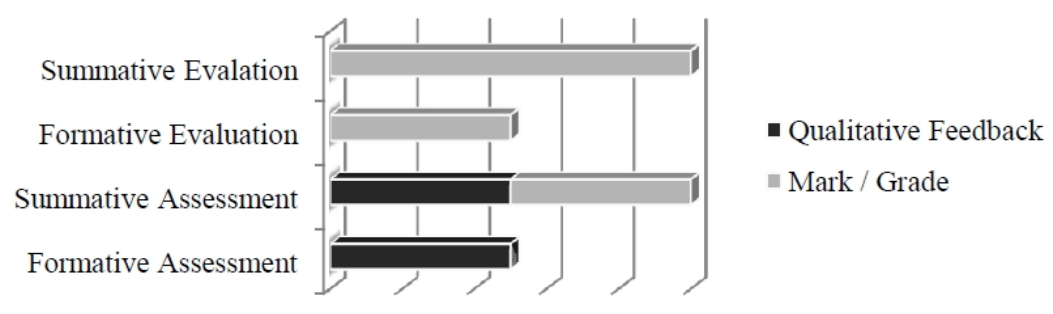

Figure 2. Types of Assessment and Evaluation

Evaluation score helps in generating a grade sheet of students of a class at the end of a course (Van HattumJanssen, Pacheco, \& Vasconcelos, 2004). Evaluation and grading, in this sense, are related to each other. 'Grading' is understood as assigning a letter or a number to a student's performance of a course at the end of a semester (Walvoord \& Anderson, 2011). It accumulates all the scores/marks received by a student in his/her performance over a semester time. It represents the overall achievement of students' learning performances of a course (Green \& Emerson, 2007). According to Sadler (2005), grading refers to the appraisal of student performance on a larger scale in which scores/marks often serve as the 'raw materials' for grade generation. Scores/marks awarded for assessment tasks are aggregated and the result is converted into a different symbolic representation of overall achievement of the student. For instance, grading symbols can be letters (A, B, C, D, etc.) with a table of numerical equivalents assigned for them. Numerical equivalents provide an easy way to the calculation of Grade Point Averages (GPAs) at the end of a semester and thereby Cumulative Grade Point Averages (CGPAs) at the end of an academic program (Sadler, 2009, 2010).

Let us explain the relationship among assessment, evaluation, and grading with an example. In an engineering course, let us say, students are asked to submit five written assignments and sit for two quizzes (quiz-1 and 2). Whether it is assignment submission or quiz, each carries 20 marks. The course teacher gives qualitative feedback on students' performance and awards a mark to the performance. The best two performance score will be counted to generate the final grade of a course. The end-semester examination carries 60 marks. So the maximum mark of a course is 100 . To generate the final score out of 100 , the best two marks out of five assignments and two quizzes can be taken and added to the end-semester examination marks. Depending on the final score, a letter grade can be assigned. For example, if a student's final score falls within the range of 82-89; the student may get a letter grade ' $A$ '. In this sense, assessment, evaluation, and grading are related to each other.

\section{THE SIGNIFICANCE OF ‘FEEDBACK’ IN ASSESSMENT PRACTICES}

The expressions 'assessment' and 'feedback' are invariably and indubitably related to each other. Feedback is considered as teacher's response to a student's performance. Assessing students performances and providing feedback on their performances is a professional approach to assessment practices (Demirkasımoğlu, 2010; Sethy, 2018). The rationale for providing feedback is to help students to use feedback comments and suggestions for the enhancement of their learning. An effective assessment necessarily offers feedback on students' performances. Assessment feedback guides students about where and how they ought to be able to go next. It has to be detailed and timely information on students' assignment performances (Boud \& Molloy, 2013).

Irons (2008) defines feedback as "an information, process or activity which affords or accelerates students' learning" (p.21). Black and Wiliam (2009) identify feedback as a key component of formative assessment. Pellegrino (2012) suggests that learning is a process of continuously modifying knowledge and skills and that feedback is essential to guide and redirect the student's thinking. According to McLean (2018), more research studies are needed to identify the impact of feedback on assessment practice.

The essential functions of feedback (Black \& Wiliam, 2009) are;

1) inform students about their present learning state,

2) inform students about the course objectives achievements, and

3) act as a means to close the gap between student's present learning state and the road to achieving other course objectives.

Course teachers are required to provide feedback on students' assignment performance. In this regard, formative assessment is "concerned with the short term collection and use of evidence for the guidance of learning, mainly in the day-to-day classroom practice" (Black \& Wiliam, 2009). Feedback provides accessible and usable 
information to students and helps them to improve their learning. In addition, it provides course teachers with an opportunity to improve the teaching-learning process of a course.

According to Nicol and Macfarlane-Dick (2006) the seven principles of good feedback practice are;

\section{Feedback requires Clarifying What is a Good Performance}

A 'good performance' by students is characterised by the achievement of predefined course learning outcomes (Suskie, 2010). Feedback requires clarifying what a good performance is with regard to course learning outcomes' achievements. Students could achieve expected course learning outcomes if they would understand each and every expected outcome clearly and unambiguously.

\section{Feedback Facilitates to Develop Self-assessment Practice in Students}

A good feedback practice encourages students to involve in self-assessment practice (Baars, Vink, van Gog, de Bruin, \& Paas, 2014). Feedback needs to communicate students' strengths and weaknesses about their course contents' learning so that they can develop the self-assessment practice on their own. In this regard, it is stated that one way to help students to develop self-assessment is to provide them with opportunities to practice it. Feedback, on this account, assists students to become self-assessors and independent learners.

\section{Feedback must Deliver Unambiguous Information to Students about their Learning}

Course teachers must try to avoid creating confusion in students' minds on their feedback suggestions and comments. According to Wiggins (2001), clear-cut feedback helps students to understand the gap between the current performance and the expected course learning outcomes. Feedback should be presented in an unambiguous language (Bayerlein, 2014; Nicol \& Milligan, 2006). It should be carefully worded to encourage students to take corrective actions on their learning.

\section{Feedback Encourages Course Teachers and Students to Involve in Peer Dialogue around Learning}

When course teachers give feedback to students on their performances, students get an opportunity to discuss the feedback among them and put an effort to rectify their shortcomings in future learning endeavour. Feedback may initiate classroom discussions between course teacher and students. Such peer dialogues are vital in improving the quality of the teaching-learning process (Deeley \& Bovill, 2015).

\section{Feedback develops Positive Motivational Beliefs in Students and Enhances their Self- esteem}

Intrinsic motivation and self-esteem play a very significant role in learning. Depending on students' beliefs about their own learning, they possess different levels of motivation and self-esteem. A well-designed feedback practice can motivate and encourage students by highlighting their strengths in learning (Nicol, 2010). It can positively influence their attitudes and beliefs about learning and boost their self-esteem.

\section{Feedback Provides Opportunities to Close the Gap between Present and Desired Performances}

Feedback should identify the gap between present and desired learning performance and communicate the same to students (Weaver, 2006). The communication has to be intelligible and unambiguous by mentioning the course contents in which students' performance needs to be improved. Feedback practice, in this sense, can help students to get an opportunity to rectify their learning mistakes and reach the desired performance level.

\section{Feedback Provides Information to Course Teachers that can be Used to Improve their Teaching Efficiency}

Feedback helps course teachers to judge their teaching efficiency by themselves (Kristensen \& Sørensen, 2004). While giving feedback on students performances, course teachers can recognise specific areas of course contents in which students are performing good or bad. Further, reasons for such performance can be traced out. The reasons may be accumulated and used to improve and reshape their teaching.

Integration of technology in assessment practices can be supportive in realising the principles of good feedback (Guzman \& Conejo, 2005; Nicol \& Milligan, 2006). In this regard, let us consider an example of technology-enabled 
assessment practice in engineering education - the 'Classroom Communication System' (CCS). According to Nicol and Boyle (2003), CCS facilitates and encourages proper feedback dialogue between the course teacher and students. Nicol and Boyle elaborate on the design implementation of CCS in an Engineering Mechanics course for a first-year engineering undergraduate class.

The basic components of the CCS are a computer, a projector to display multiple-choice questions and histograms on students' responses, clicker system transmitters for students to indicate their responses, and a software module to analyse students' responses and to make histograms (Boyle \& Nicol, 2003; Nicol \& Boyle, 2003). Different sets of multiple-choice questions are designed to assess students' comprehension of different concepts in the Engineering Mechanics course. All students in a class are allowed to indicate their responses for questions on a particular concept. Their responses are sent through clicker transmitters to course teacher's computer. The software module analyses the response and feedback results are displayed immediately as histograms in the projector. This is an example of immediate feedback, which is in line with the principle of good feedback practice (Nicol \& Macfarlane-Dick, 2006). Hence, the use of technology in student assessment can bring the motivational effect of getting immediate feedback, which would not have been possible otherwise.

The histogram feedback in CCS is followed by classroom discussions. The differences in students' responses to a particular concept as represented by histograms can be used as a trigger to initiate discussion. It can be an entire class discussion (on a concept) with course teacher as a facilitator or small group discussions. Students' conceptual reasoning and critical thinking abilities can be enhanced through further feedback from peers and course teachers who participate in the discussions. Thus, CCS leads course teachers and students to engage in peer dialogue around learning, which is another major of principle good feedback practice (Boyle \& Nicol, 2003; Sethy, 2018).

\section{IMPLICATIONS OF ASSESSMENT AND FEEDBACK IN ENGINEERING EDUCATION}

In higher education, the adoption of appropriate assessment practices in the instructional design of a course is found to have significant implications in students' learning of course contents. As elaborated in the previous sections, course teachers can motivate students' learning through assessment and feedback. Proper assessment and feedback assist students in recognising their strengths and weaknesses in specific course contents and allow them to overcome their weaknesses. By overcoming the weaknesses in a course, students not only secure good grades but also learn the subject contents thoroughly to achieve the course objectives. Thus, assessment and feedback practices can help students in achieving the learning objectives of higher education courses.

In the engineering education context, as engineering education is a part of higher education, the implications of assessment and feedback practices are similar. Assessment and feedback can support students in achieving the learning objectives of engineering education courses. In particular, assessment can be used to enhance engineering students' skills and competencies on the engineering tasks while doing engineering courses (Fernandes, Flores, \& Lima, 2012; MacLellan, 2001). According to Cruz, Saunders-Smits and Groen (2019), assessment and feedback activities can be premeditated to reflect how knowledge and skills are used in solving real-world engineering problems. Such knowledge and skills are indispensable for engineering students to become engineering professionals. The primary objective of engineering education is to help students to evolve as engineering professionals is (Lal et al., 2017; Olds, Moskal, \& Miller, 2005; Rompelman, 2000). Hence, assessment and feedback have a major implication in engineering education in accomplishing its primary objective.

In engineering disciplines, new forms of learning are introduced year after year, as engineering tasks involve in teamwork-based collaborative learning, problem-based learning, active learning, etc. With regard to new forms of learning, assessment practice on students' responses is also seeking constant modifications (Palmer, 2004). To deal with the ever-changing demands of assessment practices, course teachers need to learn the multiple assessment practice methods in the engineering education discipline. According to Felder and Silverman (1988), "The infusion of accepted principles and practices of educational theories are having a significant impact on the development of engineering curricula and the assessment practices in terms of student performance" (p.13). However, not many research studies have been conducted on assessment practices in engineering education settings.

It is argued that certain skills (e.g. analytical skills, problem-solving skills, communication skills, team working skills, etc.) required by engineering graduates are not effectively assessed by traditional assessment practices (Burtner, 2000; Iqbal \& Manarvi, 2011). Traditional assessment practices are carried out without giving importance to course learning outcomes. It focuses on reproducing the memorised knowledge of students (Suskie, 2010). In contrast, contemporary assessment practices are carefully aligned with course learning outcomes. It focuses on the enhancement of students' performance, skills, and creativity (Guzzomi, Male, \& Miller, 2015). Contemporary assessment practices are based on research findings and best practices adopted across the globe. In this sense, Olfos and Zulantay (2007) state that contemporary assessment practices can be regarded as more 'authentic' in 
comparison with traditional assessment practices. Such authentic assessment practices can adequately judge engineering students' mastery of required skills for the engineering profession. However, it is noted that an 'authentic' assessment practice does not come without costs, including 'an extraordinary time commitment' and complexity in designing such assessment tasks (Palmer, 2004; Vos, 2000). These factors contribute engineering faculty members' propensity to stick on to the traditional assessment practices.

It is a fact that no training is offered to engineering faculty members on assessment practices before joining in the academic (teaching and learning) field. So their understanding of assessing students' performance is not adequate (Palmer, 2004, p. 195). Across the globe, it is observed that no teacher-training, orientation, or training certification is required to become an engineering faculty member of a higher education institution (Bhattacharya, 2004). Even without teacher-training, engineering faculty members teach courses to students, assess and evaluate students' performance in a course. Inadequate teacher-training on assessment practices is found to be a key element, which can have a negative influence on students' course content learning (Serin, 2015).

Assessment plays a vital role in grading students' performance. It helps course teachers to find out students' achievements of a course. Further, students' achievements can be communicated to the stakeholders for prospective employment (Yorke, 2003). Conversely, it is observed that engineering skills acquired by students are not always reflected in their grade card (Sethy, 2012). Inadequacy of effective assessment practices can be attributed to this phenomenon. It leads to creating a mismatch between stakeholders and the societal expectations from students' earned skills on a course and the students' real knowledge about the course (Burtner, 2000; Yorke, 2008). The mismatch of expectations arises due to the current assessment practices in engineering education, which need to be altered to achieve aims and objectives of engineering education.

Most of the engineering institutions in the world are using norm-based assessment practices that are treated as subjective and biased assessment practices (Palmer, 2004; Sadler, 2005; Sethy, 2012). The course teachers (assessors) are judging on students' performance based on their gut feelings and previous experiences which they might have accumulated through wild guesses while studying engineering courses. As a result, the stakeholders and society fail to know what level of achievements a student has by reading the grade card of a particular course. Often it is observed that engineering faculty members are not well aware of the instructional design of a course, educational theories, assessment practices, evaluation methods and types of comments that need to be appropriately written on students' performance/assignment responses. Most of them even do not aware of how to guide students for self-assessment practices. In this regard, Fernandes, Flores, and Lima (2012) state that further research studies need to be carried out to evidently recognise engineering faculty members' perception and attitude on assessment practices.

Assessment feedback guides engineering students to monitor and regulate their learning. Lizzio and Wilson (2008) state that the implication of feedback on students' learning is in the identification of their strengths and weaknesses in their performance. Assessment feedback in this sense can develop a kind of self-regulation among students for the improvement of their learning (Nicol, 2009). Self-regulation refers to the degree to which students can regulate aspects of their thinking, motivation and behaviour during learning. The requirement for selfregulation in learning is indispensable and invaluable, as it helps students to achieve the learning outcomes in a course. If appropriate feedback is offered to students on their assignment responses, they could evolve as selfregulated learners (Nicol \& Macfarlane-Dick, 2006). Feedback enables students to identify the gap between their present performances and the desired course learning outcomes (Bayerlein, 2014). It provides guidelines on potential areas for the improvement of students' learning. Hence, assessment feedback enhances students' motivation to learn subject contents thoroughly and mindfully.

Assessment plays a pivotal role to ensure quality in higher education and thereby in engineering education (Yorke, 2008). Quality is a complex phenomenon to define in higher education set up. Quality cannot be reduced to merely a set of quantified learning outcomes (Bryan \& Clegg, 2006). Consequently, enhancing the quality of engineering education requires more than just ensuring the achievement of measurable learning outcomes at the end of the course. It further requires ensuring that engineering students are acquiring the required skills and knowledge throughout the course in order to become engineering professionals. Quality in engineering education can be ascertained to some extent through the implementation of effective assessment practices, as assessment feedback continuously monitors and improves students' performances.

In contemporary times, global interest in ensuring quality in engineering education has been intensified (Natarajan, 2000). Course teachers have identified the salient aspects of teaching excellence that lead to ensuring quality in teaching and learning tasks (Macfarlane, 2004). Some examples of such aspects include formulating clear and measurable learning objectives and aligning them with the assessment tasks, providing quality feedback in a timely manner, etc. (Deeley \& Bovill, 2015; Gaertner, 2014; Wiliam et al., 2004). These aspects highlight the significance of assessment and feedback practices in ensuring quality in engineering education settings. 


\section{CONCLUSIONS AND RECOMMENDATIONS}

This study reiterates that assessment and feedback practices play a pivotal role in achieving the aims and objectives of engineering education and thereby ensuring quality in engineering education. Assessment practices evolve from time to time with respect to innovations in course curriculum and instructional design of engineering programmes. To deal with the ever-changing scenario of engineering education setup, course teachers need to learn and adopt effective assessment practices and types of feedback that encourage and motivate students to achieve learning outcomes of the course.

However, it is observed that most of the engineering faculty members across the globe have a little or inadequate experience in formulating measurable course objectives, assessing students' performance, and providing appropriate and unambiguous feedback to students. In this context, it may be suggested that engineering faculty members may seek assistance from educational experts to learn about effective assessment and feedback strategies. Engineering faculty members may be encouraged to attend teacher-training programmes on instructional design, student assessment and feedback practices from time to time.

It is noted that most of the engineering faculty members across the globe are using the norm-referenced assessment practice to assess students' performances. However, higher education literature portrays that normreferenced assessment is not free from subjective judgements of course teachers on students' performance. Subjective and biased judgements can be reduced upon adopting the criterion-referenced assessment practice by the engineering faculty members. It is also suggested that criterion-referenced assessment practice is a professional way of assessing students' performance, which can eradicate the subjective judgements.

In higher education and thereby in engineering education, is so essential to provide qualitative feedback to students on their course content learning. Appropriate and unambiguous qualitative feedback helps students to recognise their strengths and weaknesses in learning course contents and helps them to overcome their weaknesses. Thus, proper feedback assists students in achieving course learning objectives and evolving as self-regulated learners. Formative assessment (i.e. continuous assessment with qualitative feedback) is to be carried out promptly for the benefit of students' course contents learning and course objectives achievement.

This paper is not free from limitations. Even though there are many research papers available on assessment and feedback practices in the higher education context, there are only a few relevant research studies found on the engineering education theme to review. The theoretical framework of assessment and feedback practices is not much explored in the existing engineering education research studies. This paper attempted to bring theoretical implications of assessment and feedback practices on engineering education not only from engineering education literature but also from higher education literature. However, forms of assessments, such as written examinations, oral presentations, portfolio assessments, and field visits, are not reviewed in this paper as they fall outside the scope of the present study.

There is a necessity to carry forward the research discourse on assessment and feedback practices in engineering education settings. It may be worthwhile to identify the required modifications on assessment and feedback practices in the existing engineering education settings in order to enhance the quality of engineering education. Specifically, this paper suggests the following issues for further research studies.

1) Lack of expertise of engineering educators in the design, development and implementation of assessment and feedback practices

2) Absence of a research-based standard framework for feedback practices in engineering courses

3) Shortage of guidelines on discipline-specific assessment criteria for criterion-referenced assessment in engineering education

4) Difficulty in designing assessment criteria to enhance students' practical skills in engineering laboratory work

5) Lack of assessment and feedback practices to accelerate engineering students' 'employability skills' (such as communication skills, creative thinking, lifelong learning and teamwork skills)

\section{REFERENCES}

Abdulwahed, M., \& Nagy, Z. K. (2009). Applying Kolb's Experiential Learning Cycle for Laboratory Education. Journal of Engineering Education, 98(3), 283-294. https:/ / doi.org/10.1002/j.2168-9830.2009.tb01025.x

Andersson, C., \& Palm, T. (2017). Characteristics of improved formative assessment practice. Education Inquiry, 8(2), 104-122. https:/ / doi.org/10.1080/20004508.2016.1275185

Angelo, T. A., \& Cross, K. P. (1993). Classroom assessment techniques: A handbook for college teachers. San Francisco: Jossey-Bass. 
Baars, M., Vink, S., Van Gog, T., De Bruin, A., \& Paas, F. (2014). Effects of training self-assessment and using assessment standards on retrospective and prospective monitoring of problem solving. Learning and Instruction, 33, 92-107. https:// doi.org/10.1016/j.learninstruc.2014.04.004

Bakx, A., Baartman, L. K. J., \& Van Schilt-Mol, T. (2014). Development and evaluation of a summative assessment program for senior teacher competence. Studies in Educational Evaluation, 40(1), 50-62. https:/ / doi.org/10.1016/j.stueduc.2013.11.004

Bayerlein, L. (2014). Students' feedback preferences: how do students react to timely and automatically generated assessment feedback? Assessment and Evaluation in Higher Education, 39(8), 916-931. https:/ / doi.org/10.1080/02602938.2013.870531

Bhagat, K. K., Subheesh, N. P., Bhattacharya, B., \& Chang, C. Y. (2017). The design and development of identification of students' misconceptions in individualized learning environment (iSMILE) system. Eurasia Journal of Mathematics, Science and Technology Education, 13(1), 19-34. https:/ / doi.org/10.12973/eurasia.2017.00602a

Bhattacharya, B. (2004). What is "good teaching" in engineering education in India? A case study. Innovations in Education and Teaching International, 41(3), 329-341. https:/ / doi.org/10.1080/14703290410001733258

Biggs, J. (1999). Teaching for quality learning at university. Buckingham: SRHE/Open University Press.

Black, P., \& Wiliam, D. (1998). Assessment and Classroom Learning. Assessment in Education: Principles, Policy $\mathcal{E}$ Practice, 5(1), 7-74. https:/ / doi.org/10.1080/0969595980050102

Black, P., \& Wiliam, D. (2009). Developing the theory of formative assessment. Educational Assessment, Evaluation and Accountability, 21(1), 5-31. https:/ / doi.org/10.1007/s11092-008-9068-5

Boud, D. (2000). Sustainable Assessment: Rethinking assessment for the learning society. Studies in Continuing Education, 22(2), 151-167. https:/ / doi.org/10.1080/713695728

Boud, D., \& Molloy, E. (2013). Rethinking models of feedback for learning: The challenge of design. Assessment and Evaluation in Higher Education, 38(6), 698-712. https:/ / doi.org/10.1080/02602938.2012.691462

Boud, D., Cohen, R., \& Sampson, J. (1999). Peer Learning and Assessment. Assessment E Evaluation in Higher Education, 24(4), 413-426. https:/ / doi.org/10.1080/0260293990240405

Boyle, J. T., \& Nicol, D. J. (2003). Using classroom communication systems to support interaction and discussion in large class settings. Research in Learning Technology, 11(3), 43-57. https:/ / doi.org/10.1080/0968776030110305

Bryan, C., \& Clegg, K. (Eds.). (2006). Innovative assessment in higher education. London: Routledge. https://doi.org/10.4324/9780203969670

Burtner, J. (2000). The changing role of assessment in engineering education: a review of the literature. In ASEE 2000 Southeast Section Conference (pp. 1-9).

Choudhury, P. K. (2019). Student assessment of quality of engineering education in India: evidence from a field survey. Quality Assurance in Education, 27(1), 103-126. https:/ / doi.org/10.1108/QAE-02-2015-0004

Christoforidou, M., Kyriakides, L., Antoniou, P., \& Creemers, B. P. M. (2014). Searching for stages of teacher's skills in assessment. Studies in Educational Evaluation, 40, 1-11. https:/ / doi.org/10.1016/j.stueduc.2013.11.006

Chua, K. J. (2014). A comparative study on first-time and experienced project-based learning students in an engineering design module. European Journal of Engineering Education, (July 2014), 1-17. https:/ / doi.org/10.1080/03043797.2014.895704

Clancy, E., Quinn, P., \& Miller, J. (2005). Assessment of a Case Study Laboratory to Increase Awareness of Ethical Issues in Engineering. IEEE Transactions on Education, 48(2), 313-317. https:// doi.org/10.1109/TE.2004.842900

Cruz, J. A., \& Frey, W. J. (2003). An effective strategy for integrating ethics across the curriculum in engineering: An ABET 2000 challenge. Science and Engineering Ethics, 9(4), 543-568. https:/ / doi.org/10.1007/s11948-0030049-2

Cruz, M. L., Saunders-Smits, G. N., \& Groen, P. (2019). Evaluation of competency methods in engineering education: a systematic review. European Journal of Engineering Education, 44(6), 1-29. https:/ / doi.org/10.1080/03043797.2019.1671810

Deeley, S. J., \& Bovill, C. (2015). Staff student partnership in assessment: enhancing assessment literacy through democratic practices. Assessment $\mathcal{E}$ Evaluation in Higher Education, 2938(January), 1-15. https:/ / doi.org/10.1080/02602938.2015.1126551

Demirkasımoğlu, N. (2010). Defining “Teacher Professionalism” from different perspectives. Procedia-Social and Behavioral Sciences, 9(1), 2047-2051. https:/ / doi.org/10.1016/j.sbspro.2010.12.444 
Dziob, D., Kwiatkowski, L., \& Sokolowska, D. (2018). Class tournament as an assessment method in physics courses: A pilot study. Eurasia Journal of Mathematics, Science and Technology Education, 14(4), 1111-1132. https:// doi.org/10.29333/ ejmste/81807

Ewell, P. T. (1998). National Trends in Assessing Student Learning. Journal of Engineering Education, 87(2), 107-113. https:// doi.org/10.1002/j.2168-9830.1998.tb00330.x

Felder, R. M., \& Silverman, L. K. (1988). Learning and Teaching Styles in Engineering Education. Engineering Education, 78(7), 674-681.

Fernandes, S., Flores, M. A., \& Lima, R. M. (2012). Students' views of assessment in project-led engineering education: findings from a case study in Portugal. Assessment $\mathcal{E}$ Evaluation in Higher Education, 37(2), 163178. https:// doi.org/10.1080/02602938.2010.515015

Froyd, J. E., Wankat, P. C., \& Smith, K. A. (2012). Five Major Shifts in 100 Years of Engineering Education. In Proceedings of the IEEE (Vol. 100, pp. 1344-1360). https:/ / doi.org/10.1109/JPROC.2012.2190167

Gaertner, H. (2014). Effects of student feedback as a method of self-evaluating the quality of teaching. Studies in Educational Evaluation, 42, 91-99. https:// doi.org/10.1016/j.stueduc.2014.04.003

Gibbs, G. (2006). How assessment frames student learning. In C. Bryan \& K. Clegg (Eds.), Innovative assessment in higher education (p. 23). London: Routledge.

Gibbs, G., \& Simpson, C. (2004). Conditions under which assessment supports students' learning. Learning and Teaching in Higher Education, 1(1), 3-31.

Gibbs, G., Simpson, C., \& Macdonald, R. (2003). Improving student learning through changing assessment - a conceptual and practical framework. In European Association for Research into Learning and Instruction (EARLI) Conference (pp. 1-10). Padova, Italy.

Green, K. H., \& Emerson, A. (2007). A new framework for grading. Assessment E Evaluation in Higher Education, 32(4), 495-511. https:/ / doi.org/10.1080/02602930600896571

Gulikers, J. T. M., Biemans, H. J. a., Wesselink, R., \& van der Wel, M. (2013). Aligning formative and summative assessments: A collaborative action research challenging teacher conceptions. Studies in Educational Evaluation, 39(2), 116-124. https:// doi.org/10.1016/j.stueduc.2013.03.001

Guzman, E., \& Conejo, R. (2005). Self-Assessment in a Feasible, Adaptive Web-Based Testing System. IEEE Transactions on Education, 48(4), 688-695. https:/ / doi.org/10.1109/TE.2005.854571

Guzzomi, A. L., Male, S. A., \& Miller, K. (2015). Students' responses to authentic assessment designed to develop commitment to performing at their best. European Journal of Engineering Education, 3797(January), 1-22. https:// doi.org/10.1080/03043797.2015.1121465

Hanna, G. S., \& Dettmer, P. A. (2004). Assessment for effective teaching: Using context-adaptive planning. Boston, MA: Allyn \& Bacon.

Hassan, O. A. B. (2011). Learning theories and assessment methodologies - an engineering educational perspective. European Journal of Engineering Education, 36(4), 327-339. https:/ / doi.org/10.1080/03043797.2011.591486

Hornby, W. (2003). Assessing Using Grade-related Criteria: a single currency for universities? Assessment $\mathcal{E}$ Evaluation in Higher Education, 28(4), 435-454. https:/ / doi.org/10.1080/0260293032000066254

Iqbal, A., \& Manarvi, I. A. (2011). Teachers' attitudes and perceptions for alternative assessment techniques: a case study of Pakistani universities. International Journal of Teaching and Case Studies, 3(2), 131-146. https:/ / doi.org/10.1504/IJTCS.2011.039553

Irons, A. (2008). Enhancing Learning through Formative Assessment and Feedback. New York: Routledge. https:/ / doi.org/10.4324/9780203934333

Joughin, G. (Ed.). (2009). Assessment, Learning and Judgement in Higher Education. Dordrecht: Springer Netherlands. https:/ / doi.org/10.1007/978-1-4020-8905-3

Kanjee, A., \& Sayed, Y. (2013). Assessment policy in post-apartheid South Africa: Challenges for improving education quality and learning. Assessment in Education: Principles, Policy and Practice, 20(4), 442-469. https:/ / doi.org/10.1080/0969594X.2013.838541

Knight, P. (2001). A briefing on key concepts: Formative and summative, criterion and norm-referenced assessment. Assessment Series No. 7. York, UK: LTSN Generic Centre.

Kristensen, H. J., \& Sørensen, B. L. (2004). An example of how assessment relates to practice when student learning is the main principle for creating curricula. European Journal of Engineering Education, 29(2), 203-209. https:/ / doi.org/10.1080/03043790310001633188 
Lal, S., Lucey, A. D., Lindsay, E. D., Sarukkalige, P. R., Mocerino, M., Treagust, D. F., \& Zadnik, M. G. (2017). An alternative approach to student assessment for engineering-laboratory learning. Australasian Journal of Engineering Education, 22(2), 81-94. https://doi.org/10.1080/22054952.2018.1435202

Lesage, E., Valcke, M., \& Sabbe, E. (2013). Scoring methods for multiple choice assessment in higher education - Is it still a matter of number right scoring or negative marking? Studies in Educational Evaluation, 39(3), 188-193. https:/ / doi.org/10.1016/j.stueduc.2013.07.001

Leslie, L. J., \& Gorman, P. C. (2016). Collaborative design of assessment criteria to improve undergraduate student engagement and performance. European Journal of Engineering Education, 3797(April), 1-16. https:/ / doi.org/10.1080/03043797.2016.1158791

Lizzio, A., \& Wilson, K. (2008). Feedback on assessment: Students' perceptions of quality and effectiveness. Assessment and Evaluation in Higher Education, 33(3), 263-275. https:/ / doi.org/10.1080/02602930701292548

Macfarlane, B. (2004). Teaching with Integrity: The Ethics of Higher Education Practice. London: Routledge. https://doi.org/10.4324/9780203416501

Macfarlane, B. (2009). Researching with Integrity: The Ethics of Academic Enquiry. New York: Routledge. https:/ / doi.org/10.4324/9780203886960

MacLellan, E. (2001). Assessment for Learning: The differing perceptions of tutors and students. Assessment $\mathcal{E}$ Evaluation in Higher Education, 26(4), 307-318. https:/ / doi.org/10.1080/02602930120063466

Mallet, D. G. (2008). Asynchronous online collaboration as a flexible learning activity and an authentic assessment method in an undergraduate mathematics course. Eurasia Journal of Mathematics, Science and Technology Education, 4(2), 143-151. https:/ / doi.org/10.12973/ ejmste/75314

McDowell, L., White, S., \& Davis, H. C. (2004). Changing assessment practice in engineering: how can understanding lecturer perspectives help? European Journal of Engineering Education, 29(2), 173-181. https:/ / doi.org/10.1080/03043790310001633151

McGourty, J. (1999). Four Strategies to Integrate Assessment into the Engineering Educational Environment. Journal of Engineering Education, 88(4), 391-395. https:/ / doi.org/10.1002/j.2168-9830.1999.tb00464.x

McLean, H. (2018). This is the way to teach: insights from academics and students about assessment that supports learning. Assessment and Evaluation in Higher Education, 43(8), 1228-1240. https://doi.org/10.1080/02602938.2018.1446508

Mumm, K., Karm, M., \& Remmik, M. (2016). Assessment for learning: Why assessment does not always support student teachers' learning. Journal of Further and Higher Education, 40(6), $780-803$. https:/ / doi.org/10.1080/0309877X.2015.1062847

Natarajan, R. (2000). The role of accreditation in promoting quality assurance of technical education. International Journal of Engineering Education, 16(2), 85-96.

Nicol, D. J. (2009). Assessment for learner self-regulation: enhancing achievement in the first year using learning technologies. Assessment $\mathcal{E}$ Evaluation in Higher Education, 34(3), 335-352. https:/ / doi.org/10.1080/02602930802255139

Nicol, D. J. (2010). From monologue to dialogue: improving written feedback processes in mass higher education. Assessment \& Evaluation in Higher Education, 35(5), 501-517. https:/ / doi.org/10.1080/02602931003786559

Nicol, D. J., \& Boyle, J. T. (2003). Peer instruction versus class-wide discussion in large classes: a comparison of two interaction methods in the wired classroom. Studies in Higher Education, 28(4), 457-473. https:/ / doi.org/10.1080/0307507032000122297

Nicol, D. J., \& Macfarlane-Dick, D. (2006). Formative assessment and self-regulated learning: a model and seven principles of good feedback practice. Studies in Higher Education, 31(2), 199-218. https:/ / doi.org/10.1080/03075070600572090

Nicol, D. J., \& Milligan, C. (2006). Rethinking technology-supported assessment practices in relation to the seven principles of good feedback practice. In Cordelia Bryan \& K. Clegg (Eds.), Innovative assessment in higher education (pp. 64-77). London: Routlegde.

Olds, B. M., Moskal, B. M., \& Miller, R. L. (2005). Assessment in Engineering Education: Evolution, Approaches and Future Collaborations. Journal of Engineering Education, 94(1), 13-25. https://doi.org/10.1002/j.21689830.2005.tb00826.x

Olfos, R., \& Zulantay, H. (2007). Reliability and validity of authentic assessment in a web based course. Educational Technology and Society, 10(4), 156-173. 
Oyinloye, O., \& Imenda, S. (2019). The Impact of Assessment for Learning on Learner Performance in Life Science. Eurasia Journal of Mathematics, Science and Technology Education, 15(11), 1-8. https:/ / doi.org/10.29333/ ejmste/108689

Palmer, S. (2004). Authenticity in assessment: reflecting undergraduate study and professional practice. European Journal of Engineering Education, 29(2), 193-202. https:/ / doi.org/10.1080/03043790310001633179

Pellegrino, J. W. (2012). Assessment of science learning: Living in interesting times. Journal of Research in Science Teaching, 49(6), 831-841. https:/ / doi.org/10.1002/tea.21032

Pellegrino, J. W., \& Chudowsky, N. (2003). Focus Article: The Foundations of Assessment. Measurement: Interdisciplinary Research \& Perspective, 1(2), 103-148. https:/ / doi.org/10.1207/S15366359MEA0102_01

Powell, P. C. (2004). Assessment of team-based projects in project-led education. European Journal of Engineering Education, 29(2), 221-230. https:/ / doi.org/10.1080/03043790310001633205

Rompelman, O. (2000). Assessment of student learning: Evolution of objectives in engineering education and the consequences for assessment. European Journal of Engineering Education, 25(4), 339-350. https:/ / doi.org/10.1080/03043790050200386

Rompelman, O., \& De Graaff, E. (2006). The engineering of engineering education: curriculum development from a designer's point of view 1. European Journal of Engineering Education, 31(2), 215-226. https:// doi.org/10.1080/03043790600567936

Sadler, D. R. (2005). Interpretations of criteria-based assessment and grading in higher education. Assessment $\mathcal{E}$ Evaluation in Higher Education, 30(2), 175-194. https:/ / doi.org/10.1080/0260293042000264262

Sadler, D. R. (2009). Indeterminacy in the use of preset criteria for assessment and grading. Assessment E Evaluation in Higher Education, 34(2), 159-179. https:/ / doi.org/10.1080/02602930801956059

Sadler, D. R. (2010). Fidelity as a precondition for integrity in grading academic achievement. Assessment $\mathcal{E}$ Evaluation in Higher Education, 35(6), 727-743. https:/ / doi.org/10.1080/02602930902977756

Sadler, D. R. (2012). Assessment, evaluation and quality assurance: Implications for integrity in reporting academic achievement in higher education. Education Inquiry, 3(2), 201-216. https:/ / doi.org/10.3402/edui.v3i2.22028

Scriven, M. (1967). The methodology of evaluation. In R. W. Tyler, R. M. Gagné, \& M. Scriven (Eds.), Perspectives of curriculum evaluation (AERA Monograph Series - Curriculum Evaluation) (Vol. 1). Chicago: Rand McNally and Co.

Scriven, M. (1994). Duties of the teacher. Journal of Personnel Evaluation in Education, 8(1), 151-184. https:/ / doi.org/10.1007/BF00972261

Serin, G. (2015). Alternative assessment practices of a classroom teacher: Alignment with reform-based science curriculum. Eurasia Journal of Mathematics, Science and Technology Education, 11(2), 277-297. https:/ / doi.org/10.12973/eurasia.2015.1330a

Sethy, S. S. (2012). Students' Expectations about Their Grades versus Course Expectations from Them. International Journal of Quality Assurance in Engineering and Technology Education, 2(4), 1-15. https:/ / doi.org/10.4018/ijqaete.2012100101

Sethy, S. S. (2017). Undergraduate engineering students' attitudes and perceptions towards 'professional ethics' course: a case study of India. European Journal of Engineering Education, 42(6), 987-999. https:/ / doi.org/10.1080/03043797.2016.1243656

Sethy, S. S. (2018a). Academic Ethics: Teaching Profession and Teacher Professionalism in Higher Education Settings. Journal of Academic Ethics, 16(4), 287-299. https:/ / doi.org/10.1007/s10805-018-9313-6

Sethy, S. S. (2018b). Professionalism in assessing students' performance: Roles and responsibilities of higher education teachers. In S. S. Sethy (Ed.), Higher Education and Professional Ethics (pp. 99-123). London: Routledge India. https:/ / doi.org/10.4324/9781351173803-6

Shaeiwitz, J. A. (1996). Outcomes Assessment in Engineering Education. Journal of Engineering Education, 85(3), 239 246. https:/ / doi.org/10.1002/j.2168-9830.1996.tb00239.x

Subheesh, N. P., \& Sethy, S. S. (2018). Assessment and Evaluation Practices in Engineering Education: A Global Perspective. In 3rd International Conference of the Portuguese Society for Engineering Education (CISPEE) (pp. 15). IEEE. https:/ / doi.org/10.1109/CISPEE.2018.8593451

Suskie, L. (2010). Assessing Student Learning: A Common Sense Guide. San Francisco, CA: John Wiley \& Sons.

Taras, M. (2005). Assessment - Summative and formative - Some theoretical reflections. British Journal of Educational Studies, 53(4), 466-478. https:/ / doi.org/10.1111/j.1467-8527.2005.00307.x

Taras, M. (2009). Summative assessment: the missing link for formative assessment. Journal of Further and Higher Education, 33(1), 57-69. https:/ / doi.org/10.1080/03098770802638671 
Trigwell, K., \& Prosser, M. (1991). Improving the quality of student learning: the influence of learning context and student approaches to learning on learning outcomes. Higher Education, 22(3), 251-266. https:/ / doi.org/10.1007/BF00132290

Trotter, E. (2006). Student perceptions of continuous summative assessment. Assessment and Evaluation in Higher Education, 31(5), 505-521. https:/ / doi.org/10.1080/02602930600679506

Van Hattum-Janssen, N., Pacheco, J. A., \& Vasconcelos, R. M. (2004). The accuracy of student grading in first-year engineering courses. European Journal of Engineering Education, 29(2), 291-298. https:/ / doi.org/10.1080/0304379032000157259

Vos, H. (2000). How to assess for improvement of learning. European Journal of Engineering Education, 25(3), 227-233. https:/ / doi.org/10.1080/030437900438658

Walvoord, B., \& Anderson, V. (2011). Effective grading: A tool for learning and assessment in college (2nd ed.). San Francisco: Jossey-Bass.

Weaver, M. R. (2006). Do students value feedback? Student perceptions of tutors' written responses. Assessment $\mathcal{E}$ Evaluation in Higher Education, 31(3), 379-394. https:/ / doi.org/10.1080/02602930500353061

Weurlander, M., Söderberg, M., Scheja, M., Hult, H., \& Wernerson, A. (2012). Exploring formative assessment as a tool for learning: students' experiences of different methods of formative assessment. Assessment $\mathcal{E}$ Evaluation in Higher Education, 37(6), 747-760. https:/ / doi.org/10.1080/02602938.2011.572153

Wiggins, G. (2001). Educative assessment. San Francisco: Jossey-Bass.

Wiliam, D., Lee, C., Harrison, C., \& Black, P. (2004). Teachers developing assessment for learning: impact on student achievement. Assessment in Education: Principles, Policy $\mathcal{E}$ Practice, 11(1), 49-65. https:/ / doi.org/10.1080/0969594042000208994

Worth-Butler, M. M., Murphy, R. J. L., \& Fraser, D. M. (1994). Towards an integrated model of competence in midwifery. Midwifery, 10(4), 225-231. https:/ / doi.org/10.1016/0266-6138(94)90057-4

Yorke, M. (2003). Transition into higher education: some implications for the 'employability agenda.' York: Higher Education Academy.

Yorke, M. (2008). Grading Student Achievement in Higher Education. London: Routledge. https:// doi.org/10.4324/9780203939413

\section{http://www.ejmste.com}

